\title{
One-step hydrothermal synthesis and electrochemical performance of sodium-manganese-iron phosphate as cathode material for Li-ion batteries ${ }^{\text {is }}$
}

\author{
Claude Karegeya ${ }^{\mathrm{a}}$, Abdelfattah Mahmoud ${ }^{\mathrm{a}, *}$, Bénédicte Vertruyen ${ }^{\mathrm{a}}$, Frédéric Hatert ${ }^{\mathrm{b}}$, Raphaël \\ P. Hermann ${ }^{\mathrm{c}}$, Rudi Cloots ${ }^{\mathrm{a}}$, Frédéric Boschini ${ }^{\mathrm{a}}$ \\ a GREENMAT, CESAM, Institute of Chemistry B6, University of Liège, 4000 Liège, Belgium \\ b Laboratory of Mineralogy B18, University of Liège, 4000 Liège, Belgium \\ c Materials Science and Technology Division, Oak Ridge National Laboratory, Oak Ridge, TN 37831, USA
}

\section{A R T I C L E I N F O}

\section{Keywords:}

$\mathrm{Na}_{2} \mathrm{Mn}_{1.5} \mathrm{Fe}_{1.5}\left(\mathrm{PO}_{4}\right)_{3}$

Alluaudite structure type

Hydrothermal synthesis

Crystal structure refinement

Mössbauer spectroscopy

Energy storage

\begin{abstract}
A B S T R A C T
The sodium-manganese-iron phosphate $\mathrm{Na}_{2} \mathrm{Mn}_{1.5} \mathrm{Fe}_{1.5}\left(\mathrm{PO}_{4}\right)_{3}$ (NMFP) with alluaudite structure was obtained by a one-step hydrothermal synthesis route. The physical properties and structure of this material were obtained through XRD and Mössbauer analyses. X-ray diffraction Rietveld refinements confirm a cationic distribution of $\mathrm{Na}^{+}$and presence of vacancies in $\mathrm{A}(2)^{\prime}, \mathrm{Na}^{+}$and small amounts of $\mathrm{Mn}^{2+}$ in $\mathrm{A}(1), \mathrm{Mn}{ }^{2+}$ in $\mathrm{M}(1)$, $0.5 \mathrm{Mn}^{2+}$ and $\mathrm{Fe}$ cations $\left(\mathrm{Mn}^{2+}, \mathrm{Fe}^{2+}\right.$ and $\left.\mathrm{Fe}^{3+}\right)$ in $\mathrm{M}(2)$, leading to the structural formula $\mathrm{Na}_{2} \mathrm{Mn}_{(}\left(\mathrm{Mn}_{0.5} \mathrm{Fe}_{1.5}\right)$ $\left(\mathrm{PO}_{4}\right)_{3}$. The particles morphology was investigated by SEM. Several reactions with different hydrothermal reaction times were attempted to design a suitable synthesis protocol of NMFP compound. The time of reaction was varied from 6 to $48 \mathrm{~h}$ at $220^{\circ} \mathrm{C}$. The pure phase of NMFP particles was firstly obtained when the hydrothermal reaction of NMFP precursors mixture was maintained at $220{ }^{\circ} \mathrm{C}$ for $6 \mathrm{~h}$. When the reaction time was increased from 6 to 12, 24 and $48 \mathrm{~h}$, the dandelion structure was destroyed in favor of NMFP micro-rods. The combination of NMFP (NMFP-6H, NMFP-12H, NMFP-24H and NMFP-48H) structure refinement and Mössbauer characterizations shows that the increase of the reaction time leads to the progressive increment of Fe(III) and the decrease of the crystal size. The electrochemical tests indicated that NMFP is a $3 \mathrm{~V}$ sodium intercalating cathode. The comparison of the discharge capacity evolution of studied NMFP electrode materials at C/5 current density shows different capacities of 48, 40, 34 and $34 \mathrm{~mA} \mathrm{~h} \mathrm{~g}^{-1}$ for NMFP-6H, NMFP-12H, NMFP-24H and NMFP-48H respectively. Interestingly, all samples show excellent capacity retention of about $99 \%$ during 50 cycles.
\end{abstract}

\section{Introduction}

In the last decades, extensive research around structure characterizations of alluaudite materials has been conducted and reported by Fisher et al, Moore et al., Fontan et al., Leroux et al., Korzenski et al. and Hatert et al. [1-6]. Fisher determined the unit-cell parameters of natural alluaudite, and Moore used a single crystal of alluaudite from the Buranga pegmatite, Rwanda, to determine the crystal structure of alluaudite in the monoclinic $C 2 / c$ space group [1,2]. The latter proposed the general structural formula $\mathrm{X}(2) \mathrm{X}(1) \mathrm{M}(1) \mathrm{M}(2)_{2}\left(\mathrm{PO}_{4}\right)_{3}$, with $\mathrm{Z}=4$ [2]. In his formula, the large $\mathrm{X}(2)$ site contains $\mathrm{Na}, \mathrm{K}$, and vacancies, $\mathrm{X}(1)$ contains $\mathrm{Na}, \mathrm{Mn}$, and $\mathrm{Ca}, \mathrm{M}(1)$ contains $\mathrm{Mn}$ and $\mathrm{Fe}^{2+}$, and the small $\mathrm{M}(2)$ site contains $\mathrm{Fe}^{3+}, \mathrm{Fe}^{2+}, \mathrm{Mn}, \mathrm{Mg}$, and Li. Because Mn generally dominates on the $\mathrm{M}(1)$ site, and $\mathrm{Fe}^{2+}$ and $\mathrm{Fe}^{3+}$ dominate on the $\mathrm{M}(2)$ site, Moore proposed the ideal formula of manganese-iron phosphate-based alluaudite, $\mathrm{Na}_{2} \mathrm{MnFe}^{2+} \mathrm{Fe}^{3+}\left(\mathrm{PO}_{4}\right)_{3}$ (Fig. 1), from which the majority of natural alluaudites can be derived [6]. The successive studies on synthetic samples revealed new cationic sites in the channels of the structure [6,7], which were not observed by Moore. Hatert et al. completed the alluaudite structure model of Moore and proposed the general formula of alluaudite compounds as [A(2)A(2)'] $\left[\mathrm{A}(1) \mathrm{A}(1) \mathrm{A}(1)^{\prime \prime}{ }_{2}\right] \mathrm{M}(1) \mathrm{M}(2)_{2}\left(\mathrm{PO}_{4}\right)_{3}$ [6]. In the geological context of

\footnotetext{
Notice: This manuscript has been authored by UT-Battelle, LLC, under Contract no. DE-AC0500OR22725 with the U.S. Department of Energy. The United States Government

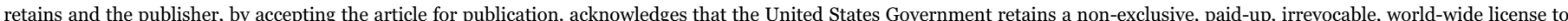

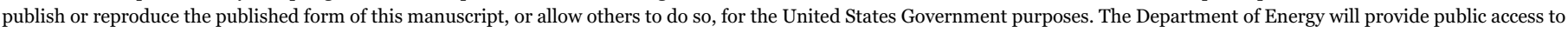
these results of federally sponsored research in accordance with the DOE Public Access Plan.

* Corresponding author.

E-mail addresses: abdelfattah.mahmoud@ulg.ac.be, mahmoudrca@gmail.com (A. Mahmoud).
} 


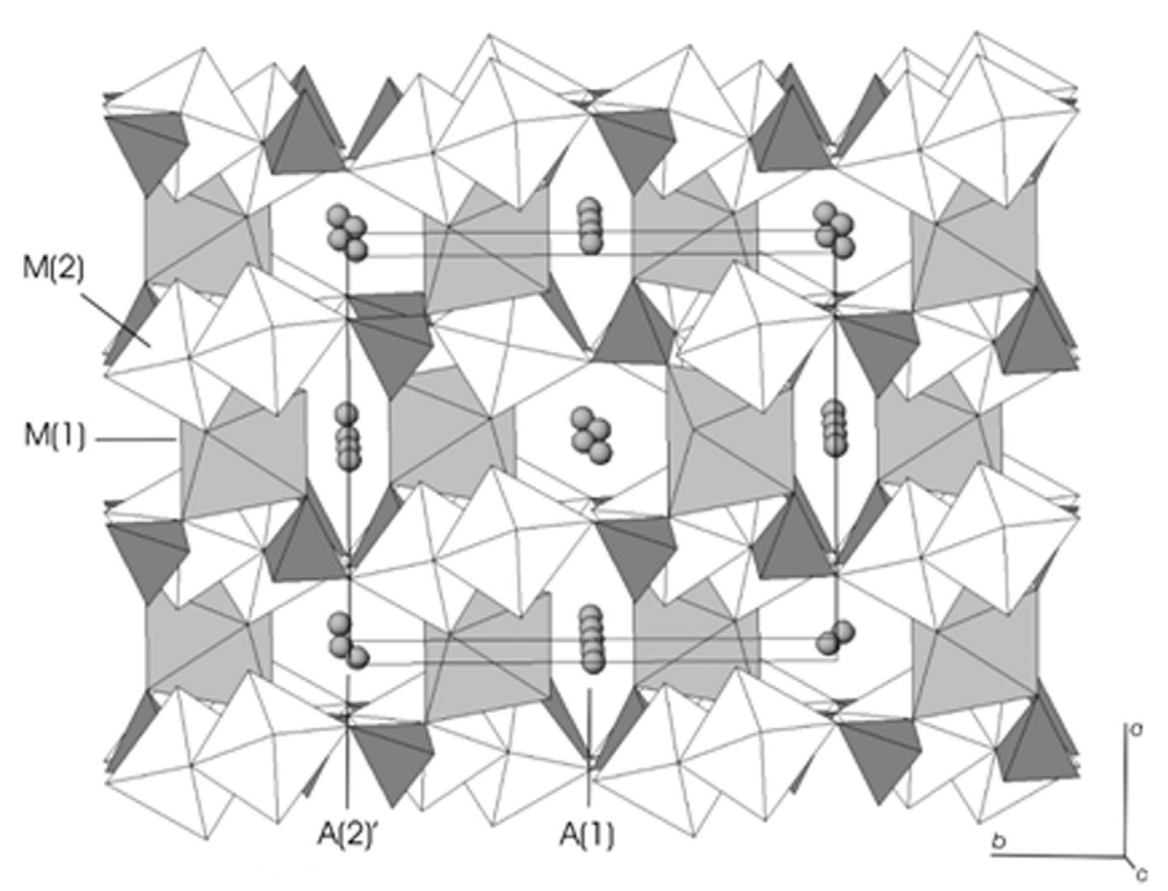

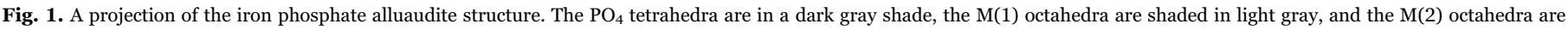
unshaded. The circles denote $\mathrm{Na}$ at the $\mathrm{A}(1)$ and $\mathrm{A}(2)^{\prime}$ ' crystallographic sites.

granitic pegmatites, alluaudite exhibits chemical compositions ranging from $\mathrm{Na}_{2} \mathrm{Mn}\left(\mathrm{Fe}^{2+} \mathrm{Fe}^{3+}\right)\left(\mathrm{PO}_{4}\right)_{3}$ to $\square \mathrm{NaMnFe}_{2}{ }^{3+}\left(\mathrm{PO}_{4}\right)_{3}$, with $\mathrm{Mn}^{2+}$ or some $\mathrm{Ca}^{2+}$ replacing $\mathrm{Na}^{+}$at the $\mathrm{A}(1)$ site, $\mathrm{Fe}^{2+}$ replacing $\mathrm{Mn}^{2+}$ at the $\mathrm{M}(1)$ site, and some $\mathrm{Mg}^{2+}$ or $\mathrm{Mn}^{2+}$ replacing iron at the $\mathrm{M}(2)$ site, where $\square$ represents a lattice vacancy at the $A(2)$ ' site [6]. These vacancies and the general open-framework structure of alluaudite-type compounds explain why they easily intercalate/deintercalate $\mathrm{Li}$ and Na-ions; in addition iron phosphate-based alluaudites show high thermal stability. All above reasons classified them among various potential promising polyanionic electrode materials in lithium-ion batteries (LIBs) and sodium-ion batteries (SIBs) [8-12]. Electrochemical characterizations of alluaudite materials were first reported by Durio and Richardson [13,14]. In their reports, they showed that these materials are promising electrode materials for Liion batteries. Several iron phosphate-based alluaudite compounds, $\mathrm{Na}_{1.86} \square_{0.14} \mathrm{Fe}_{3}\left(\mathrm{PO}_{4}\right)_{3}, \quad \mathrm{Li}_{0.5} \mathrm{Na}_{0.5} \mathrm{MnFe}_{2}\left(\mathrm{PO}_{4}\right)_{3}$ and $\mathrm{Li}_{0.75} \mathrm{Na}_{0.25}$ $\mathrm{MnFe}_{2}\left(\mathrm{PO}_{4}\right)_{3}, \mathrm{Na}_{2} \mathrm{Fe}_{3-\mathrm{x}} \mathrm{Mn}_{\mathrm{x}}\left(\mathrm{PO}_{4}\right)_{3}$, and $\mathrm{Na}_{3} \mathrm{Fe}_{3}\left(\mathrm{PO}_{4}\right)_{4}$ show interesting electrochemical properties as electrode materials and received continued attention to improve the electrochemical properties of the current LIBs and SIBs [15-18].

The sodium based cathodes for $\mathrm{Li}$ and $\mathrm{Na}$-ion batteries are currently considered as potential alternative of their lithiated counterparts because sodium is an unexpensive, abundant, and widely distributed metal [19]. Secondly, compared to Li, $\mathrm{Na}$ has almost equal physical and chemical properties. Therefore, after lithium, the electrochemical equivalent and standard potential of sodium are the most advantageous for aprotic battery applications [20,21]. Furthermore, the optimization of synthesis conditions is required in order to prepare particles with controlled size and morphology associated with desired chemical compositions [22].

In this context our aim is to provide a one-step hydrothermal synthesis of sodium-based alluaudite, $\mathrm{Na}_{2} \mathrm{Mn}_{1.5} \mathrm{Fe}_{1.5}\left(\mathrm{PO}_{4}\right)_{3}$ (NMFP), at low temperature [23], design the synthesis protocol, and analyze its effect on particle morphology. The physical properties were characterized by Rietveld refinement of X-ray diffraction data and Mössbauer spectral analysis. Electrochemical performances of NMFP as cathode materials were studied in a Li-sodium hybrid half cell configuration.

\section{Experimental section}

\subsection{Chemicals}

Sodium dihydrogen phosphate dihydrate $\left(\mathrm{NaH}_{2} \mathrm{PO}_{4} \cdot \mathrm{H}_{2} \mathrm{O}, \geq\right.$ 99.0\%), manganese carbonate $\left(\mathrm{MnCO}_{3}, \geq 99.9 \%\right)$, iron oxalate $\left(\mathrm{FeC}_{2} \mathrm{O}_{4} .2 \mathrm{H}_{2} \mathrm{O}, 99.0 \%\right)$ and sodium nitrate $\left(\mathrm{NaNO}_{3}, \geq 99.0 \%\right)$ were purchased from Sigma- Aldrich. Carbon black was obtained from Alfa Aesar. All chemicals were used as received without further purification. In our synthesis protocol, we used Milli-Q ultrapure water with a resistivity higher than $18.2 \mathrm{M} \Omega \mathrm{cm}$.

\subsection{Synthesis}

The typical hydrothermal synthesis of NMFP material was achieved by dissolving precursors in water and exposing the mixture at moderate temperature. In this process, $0.624 \mathrm{~g}$ of $\mathrm{NaH}_{2} \mathrm{PO}_{4} \cdot \mathrm{H}_{2} \mathrm{O}, 0.680 \mathrm{~g}$ of $\mathrm{NaNO}_{3}, 0.223 \mathrm{~g}$ of $\mathrm{MnCO}_{3}$ and $0.359 \mathrm{~g}$ of $\mathrm{FeC}_{2} \mathrm{O}_{4} \cdot 2 \mathrm{H}_{2} \mathrm{O}$ were dissolved in $60 \mathrm{~mL}$ of milli-Q water and stirred for about $30 \mathrm{~min}$ at room temperature under argon. The reaction mixture was then sealed into a $125 \mathrm{~mL}$ Teflon-lined stainless steel autoclave, heated at $220^{\circ} \mathrm{C}$ for $6 \mathrm{~h}$ and cooled down to room temperature. In different reactions, the hydrothermal reaction time was increased to 12,24 and $48 \mathrm{~h}$. The final products (NMFP-6H, NMFP-12H, NMFP-24H and NMFP-48H) were collected by gravimetric filtration, washed with water and ethyl alcohol three times for each one respectively, and then dried in an electric oven under vacuum at $80{ }^{\circ} \mathrm{C}$ for $2 \mathrm{~h}$.

\subsection{Crystalline phase and particle morphology analysis}

Powder X-ray diffraction (XRD) data was collected on a Panalytical PW-3710 powder diffractometer using FeKa radiation $(\lambda=1.9373 \AA$ ), operating from $2 \theta=10-100^{\circ}$. The crystal structure was refined by the Rietveld method, starting from the observed powder diffraction pattern and using the DBWS-9807 software [24]. Scanning electronic microscopy (SEM) was used to characterize the particle size and morphology of the different NMFP powders. The SEM morphological analysis on the NMFP samples were performed on a FEG-ESEM XL30 (FEI) with 
an accelerating voltage of $15 \mathrm{kV}$ under high vacuum. Samples were deposited on carbon tapes. Sputtering deposition was done with gold target under argon atmosphere (Balzers, SCD004, Sputter coater).

\section{4. ${ }^{57} \mathrm{Fe}$ Mössbauer spectroscopy}

${ }^{57} \mathrm{Fe}$ transmission Mössbauer spectroscopy data were recorded by using a constant-acceleration spectrometer with a ${ }^{57} \mathrm{Co}(\mathrm{Rh})$ source at room temperature. The Mössbauer spectral absorbers were prepared with $30 \mathrm{mg}$ of NMFP materials mixed with boron nitride. The spectrometer was calibrated at room temperature with the magnetically split sextet spectrum of a high-purity $\alpha-F e$ foil as the reference absorber. The measurements were carried out in the $\pm 4 \mathrm{mms}^{-1}$ velocity ranges with optimal energy resolution. The Mössbauer spectra were fitted using Lorentzian doublets using the Fullham program [25]. In this way, spectral parameters such as isomer shift $(\delta)$, quadrupole splitting $(\Delta)$, linewidth $(\Gamma)$ and relative resonance areas of the different spectral components were determined. The validity of fits was judged on the basis of minimizing the number of parameters and $x$ values $(x<0.1)$.

\subsection{Thermal gravimetric analysis (TGA) and differential scanning calorimetry (DSC)}

Thermal gravimetric analysis (TGA) and differential scanning calorimetry (DSC) were carried out on a Lab Sys evo TGA-DTA-DSC, the samples were analyzed from $25^{\circ} \mathrm{C}$ to $1000{ }^{\circ} \mathrm{C}$ at a heating rate of $2.5^{\circ} \mathrm{C} / \mathrm{min}$ under a flow of dry air. The weight of the samples was about $15 \mathrm{mg}$.

\subsection{Electrochemical measurements}

Electrochemical measurements were conducted in two-electrode Swagelock $^{\mathrm{TM}}$ cells, using Lithium metal (Aldrich) as anode material which also operated as a reference electrode, and $1 \mathrm{M} \mathrm{LiPF}_{6}$ in ethylene carbonate/dimethylcarbonate $(1 / 1, \mathrm{v} / \mathrm{v})$ as electrolyte solution. NMFP powders were mixed with carbon black and polyvinylidene fluoride to reach a 60:20:20 weight ratio, then were mixed together for $30 \mathrm{~min}$. $13 \mathrm{~mm}$-diameter pellets were prepared by uniaxial sample pressing on a stainless steel grid. The current collectors were stainless steel and the separator between electrodes was a $25 \mu \mathrm{m}$ monolayer polypropylene membrane (Celgard type).

The electrochemical cells were assembled in an argon glove box and room temperature cyclic voltammetry (CV) analysis was performed in the range of $1.5-4.5 \mathrm{~V}$ at $0.5 \mathrm{mV} \mathrm{s}^{-1}$. The galvanostatic charge/ discharge curves were measured using a multichannel Biologic potentiostat (VMP3) between 1.5 and $4.5 \mathrm{~V} \mathrm{vs} \mathrm{Li}^{+} / \mathrm{Li}^{\circ}$ at different cycling rates.

\section{Results and discussion}

\subsection{Material structure analysis}

The crystal structure of $\mathrm{Na}_{2} \mathrm{Mn}_{1.5} \mathrm{Fe}_{1.5}\left(\mathrm{PO}_{4}\right)_{3}$ obtained by hydrothermal synthesis at $220{ }^{\circ} \mathrm{C}$ for $6,12,24$ and $48 \mathrm{~h}$ was refined using the atomic coordinates of $\square_{0.5} \mathrm{Na}_{1.5} \mathrm{Mn}_{1.5} \mathrm{Fe}_{1.5}\left(\mathrm{PO}_{4}\right)_{3}$ as a starting model [26]. The NMFP powder XRD patterns are in good agreement with the predicted patterns on the basis of crystallization of the target alluaudite phase. Details of the refinements are given in Tables 1 and $\mathrm{S} 1$, which clearly show that the unit-cell parameters are comparable to those of other alluaudite-type phosphates $[6,8,10]$.

There is no obvious correlation between the crystallinity (FWHM), and the duration of the hydrothermal synthesis. However the longer duration of reaction favor the better ordering of cations on their respective sites.

The final Rietveld plot for sample NMFP-12H is given in Fig. 2 as an example. The atomic coordinates, obtained from the Rietveld
Table 1

Experimental details for the Rietveld refinement of the $\mathrm{Na}_{2} \mathrm{Mn}_{1.5} \mathrm{Fe}^{2+}{ }_{0.5} \mathrm{Fe}^{3+}\left(\mathrm{PO}_{4}\right)_{3}$ alluaudite-type phosphates.

\begin{tabular}{lllll}
\hline No. & NMFP-6H & NMFP-12H & NMFP-24H & NMFP-48H \\
\hline Number of reflexions & 505 & 502 & 534 & 524 \\
Refined parameters & 43 & 45 & 43 & 45 \\
Positional & 27 & 27 & 27 & 27 \\
Population & 3 & 3 & 3 & 3 \\
Thermal & 3 & 5 & 3 & 5 \\
Cell parameters & 4 & 4 & 4 & 4 \\
Profile & 2 & 2 & 2 & 2 \\
Zero point ( ${ }^{\circ}$ 20) & 1 & 1 & 1 & 1 \\
Sample displacement & 1 & 1 & 1 & 1 \\
Scale factor & 1 & 1 & 1 & 1 \\
Preferred orientation & 1 & 1 & 1 & 1 \\
& & & & $11.933(1)$ \\
$a(\AA)$ & $11.992(1)$ & $11.953(1)$ & $11.915(1)$ & $12.533(1)$ \\
$b(\AA)$ & $12.624(1)$ & $12.563(1)$ & $12.522(1)$ & $6.454(1)$ \\
$c(\AA)$ & $6.513(1)$ & $6.473(1)$ & $6.453(1)$ & $114.87(1)$ \\
$\beta\left({ }^{\circ}\right)$ & $115.02(1)$ & $114.93(1)$ & $114.91(1)$ & \\
& & & & 2.70 \\
$\mathrm{R}_{\mathrm{p}}(\%)$ & 2.89 & 2.23 & 2.39 & 1.63 \\
$\mathrm{R}_{\text {wp }(\%)}$ & 3.76 & 2.96 & 3.30 & 2.46 \\
$\mathrm{R}_{\text {exp. }}(\%)$ & 1.59 & 1.70 & 1.60 & 8.25 \\
$\mathrm{~S}($ GooF) & 2.36 & 1.74 & 2.05 & \\
$\mathrm{R}_{\text {Bragg }}(\%)$ & 15.97 & 8.88 & 7.80 & \\
\hline & & & & \\
\hline
\end{tabular}

refinement of sample NMFP-12H, are given in Table 2, they are similar to those of similar alluaudite-type compounds, as for example the samples investigated by Hatert et al. [8,10]. The significant distortion of the $\mathrm{P}(1)-\mathrm{O}_{4}$ tetrahedron was previously observed for the compound $\mathrm{Na}_{2} \mathrm{Mn}_{2} \mathrm{Fe}^{3+}\left(\mathrm{PO}_{4}\right)_{3}$ synthesized by solid state reaction at $850^{\circ} \mathrm{C}$ by Hatert et al. [10], as well as for alluaudites of the $\mathrm{Na}_{2}$ $\left(\mathrm{Mn}_{1-\mathrm{x}} \mathrm{Fe}^{2+}{ }_{\mathrm{x}}\right)_{2} \mathrm{Fe}^{3+}\left(\mathrm{PO}_{4}\right)_{3}$ solid solution, synthesized hydrothermally at $400{ }^{\circ} \mathrm{C}$ by Hatert et al. [8]. The reasons of this high tetrahedral distortion are not explained, but they affect the most Mn-rich samples, thus indicating a possible correlation between the $\mathrm{P}(1)-\mathrm{O}$ distortion, and the Mn-content of alluaudite-type phosphates". The interatomic distances are listed in Table 3. No significant differences were observed, compared to interatomic distances in $\square_{0.5} \mathrm{Na}_{1.5} \mathrm{Mn}_{1.5} \mathrm{Fe}_{1.5}\left(\mathrm{PO}_{4}\right)_{3}$ [26].

The refinement of the occupancies indicated the presence of sodium deficiency at the $\mathrm{A}(2)$ ' site, as well as a small amount of $\mathrm{Mn}^{2+}$ on the A(1) position. Such disordered cationic distributions are relatively common in alluaudite-type phosphates $[8,10,11]$. Cationic distributions, for the alluaudite-type phosphates synthesized in this study are given in the Table S2. They were calculated according to the results of the Mössbauer spectral measurements, as well as to the site occupancy factors obtained from the Rietveld refinements. An iterative calculation procedure was used, to reach charge balance for each compound, maintaining the $\mathrm{Fe}^{2+} / \mathrm{Fe}^{3+}$ ratios determined by Mössbauer spectrometry. The less intense $\mathrm{Fe}^{2+}$ doublet, observed on the Mössbauer spectra, was assigned to $\mathrm{Fe}^{2+}$ on the $\mathrm{M}(1)$ site, as discussed below. From these distributions, it appears that significant amounts of $\mathrm{Fe}^{2+}$ occupy the M(1) site, and that significant amounts of Mn occupy on $\mathrm{M}(2)$. This disordered distribution of Fe and Mn on the M(1) and M(2) sites is common in synthetic alluaudite-type phosphates $[8,10]$. For the compounds obtained after a short reaction time, it also appears that significant amounts of $\mathrm{Mn}$ occupy on the A(1) site, while at $48 \mathrm{~h}$ reaction, the composition is very close to the ideal formula $\mathrm{Na}_{2} \mathrm{MnFe}(\mathrm{II}) \mathrm{Fe}(\mathrm{III})\left(\mathrm{PO}_{4}\right)_{3}$.

The presence of $\mathrm{Mn}$ on the $\mathrm{A}(1)$ site implies a charge excess, which is compensated by the increase of the $\mathrm{Fe}(\mathrm{II}) /(\mathrm{Fe}(\mathrm{II})+\mathrm{Fe}(\mathrm{III}))$ ratio, according to the Mössbauer spectral results. The substitution mechanism, which explains the incorporation of $\mathrm{Mn}$ on the $\mathrm{A}(1)$ site, corresponds to: $\mathrm{Na}_{\mathrm{A} 1}^{+}+\mathrm{Fe}^{3+}{ }_{\mathrm{M} 2}=\mathrm{Mn}^{2+}{ }_{\mathrm{A} 1}+\mathrm{Fe}^{2+}{ }_{\mathrm{M} 2}$. This mechanism has been observed previously by Hatert in hydrothermally-synthesized alluaudite-type phosphates [27]. 


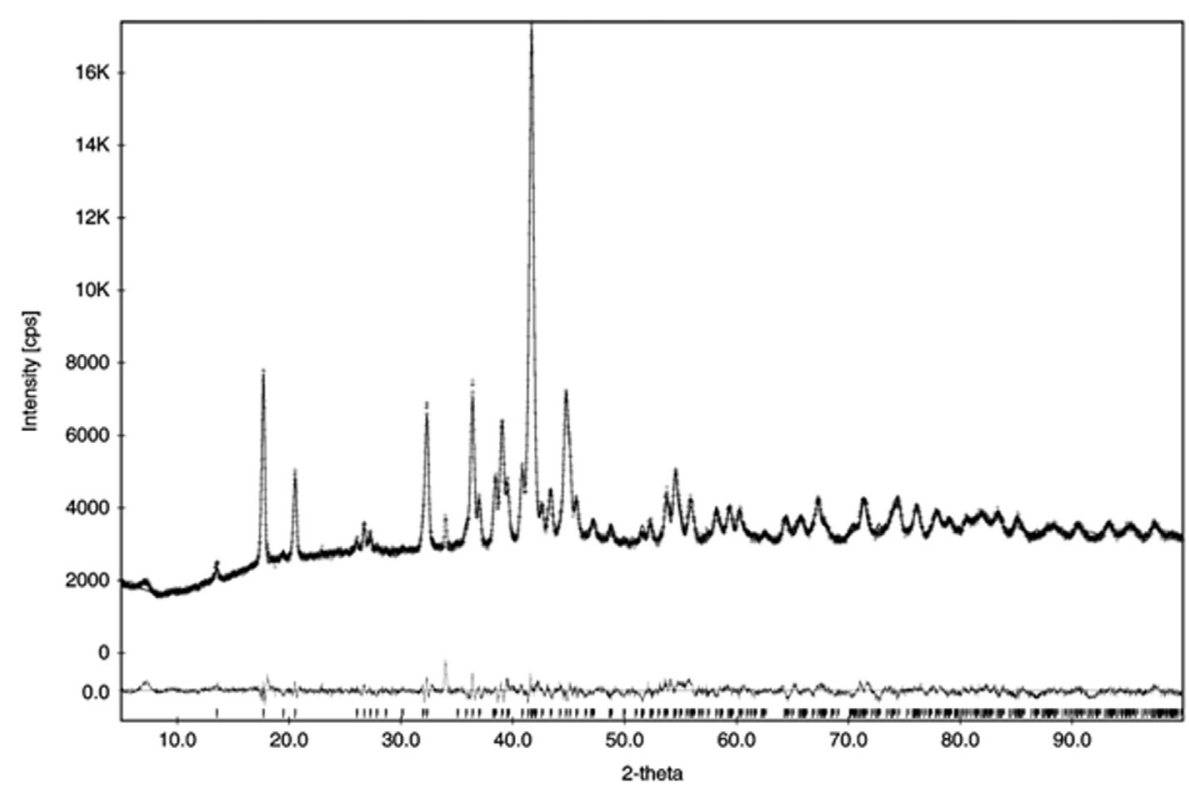

Fig. 2. Final observed, calculated, and difference plots for XRPD (FeKa radiation) Rietveld refinement of $\mathrm{Na}_{2} \mathrm{Mn}_{1.5} \mathrm{Fe}_{1.5}\left(\mathrm{PO}_{4}\right)_{3}(\mathrm{sample} \mathrm{NMFP}-12 \mathrm{H})$.

Table 2

Positional $(x, y, z)$, isotropic thermal $(B)$ and site occupancy $(N)$ parameters for the $\mathrm{Na}_{2} \mathrm{Mn}_{1.5} \mathrm{Fe}^{2+}{ }_{0.5} \mathrm{Fe}^{3+}\left(\mathrm{PO}_{4}\right)_{3}$ alluaudite-type compound (sample NMFP-12H).

\begin{tabular}{llllllll}
\hline Site & Atom & Wyckoff & $X$ & $Y$ & $Z$ & $B\left(\AA^{2}\right)$ & $N$ \\
\hline $\mathrm{A}(2)$ & $\mathrm{Na}$ & $4 e$ & 0 & $-0.0185(8)$ & $1 / 4$ & 1.0 & $0.934(9)$ \\
$\mathrm{A}(1)$ & $\mathrm{Na}$ & $4 b$ & $1 / 2$ & 0 & 0 & $1.5(4)$ & $0.86(2)$ \\
& $\mathrm{Mn}$ & $4 b$ & $1 / 2$ & 0 & 0 & $1.5(4)$ & $0.14(2)$ \\
$\mathrm{M}(1)$ & $\mathrm{Mn}$ & $4 e$ & 0 & $0.2689(5)$ & $1 / 4$ & $1.3(3)$ & $0.99(1)$ \\
$\mathrm{M}(2)$ & $\mathrm{Fe}$ & $8 f$ & $0.2816(5)$ & $0.6585(3)$ & $0.3586(8)$ & $3.3(1)$ & 0.75 \\
& $\mathrm{Mn}$ & $8 f$ & $0.2816(5)$ & $0.6585(3)$ & $0.3586(8)$ & $3.3(1)$ & 0.25 \\
$\mathrm{P}(1)$ & $\mathrm{P}$ & $4 e$ & 0 & $-0.2807(9)$ & $1 / 4$ & $5.3(2)$ & 1.0 \\
$\mathrm{P}(2)$ & $\mathrm{P}$ & $8 f$ & $0.2202(8)$ & $-0.1036(6)$ & $0.125(2)$ & $5.3(2)$ & 1.0 \\
$\mathrm{O}(1)$ & $\mathrm{O}$ & $8 f$ & $0.465(1)$ & $0.7062(8)$ & $0.545(2)$ & $2.3(2)$ & 1.0 \\
$\mathrm{O}(2)$ & $\mathrm{O}$ & $8 f$ & $0.115(1)$ & $0.6297(8)$ & $0.271(2)$ & $2.3(2)$ & 1.0 \\
$\mathrm{O}(3)$ & $\mathrm{O}$ & $8 f$ & $0.341(1)$ & $0.6608(8)$ & $0.107(2)$ & $2.3(2)$ & 1.0 \\
$\mathrm{O}(4)$ & $\mathrm{O}$ & $8 f$ & $0.134(1)$ & $0.4056(9)$ & $0.322(2)$ & $2.3(2)$ & 1.0 \\
$\mathrm{O}(5)$ & $\mathrm{O}$ & $8 f$ & $0.2159(9)$ & $0.8364(8)$ & $0.320(2)$ & $2.3(2)$ & 1.0 \\
$\mathrm{O}(6)$ & $\mathrm{O}$ & $8 f$ & $0.3396(7)$ & $0.503(1)$ & $0.392(1)$ & $2.3(2)$ & 1.0 \\
\hline
\end{tabular}

Table 3

Interatomic distances $(\AA)$ and angles $O-P-O \quad\left(^{\circ}\right)$ for the synthetic $\mathrm{Na}_{2} \mathrm{Mn}_{1.5} \mathrm{Fe}^{2+}{ }_{0.5} \mathrm{Fe}^{3+}\left(\mathrm{PO}_{4}\right)_{3}$ alluaudite-type compound.

\begin{tabular}{llll}
\hline $\mathrm{A}(2)^{\prime}-\mathrm{O}(6) \times 2$ & $2.311(7)$ & $\mathrm{A}(1)-\mathrm{O}(2) \times 2$ & $2.36(1)$ \\
$\mathrm{A}(2)^{\prime}-\mathrm{O}(6) \times 2$ & $2.465(6)$ & $\mathrm{A}(1)-\mathrm{O}(4) \times 2$ & $2.34(1)$ \\
$\mathrm{A}(2)^{\prime}-\mathrm{O}(1) \times 2$ & $2.66(1)$ & $\mathrm{A}(1)-\mathrm{O}(4) \times 2$ & $2.62(1)$ \\
$\mathrm{A}(2)^{\prime}-\mathrm{O}(3) \times 2$ & $2.84(1)$ & $\mathrm{A}(1)-\mathrm{O}(2) \times 2$ & $2.909(9)$ \\
Mean & $\mathbf{2 . 5 7}$ & $\mathrm{Mean}$ & $\mathbf{2 . 5 6}$ \\
$\mathrm{M}(1)-\mathrm{O}(4) \times 2$ & $2.26(1)$ & $\mathrm{M}(2)-\mathrm{O}(6)$ & $2.06(1)$ \\
$\mathrm{M}(1)-\mathrm{O}(1) \times 2$ & $2.23(1)$ & $\mathrm{M}(2)-\mathrm{O}(2)$ & $1.863(9)$ \\
$\mathrm{M}(1)-\mathrm{O}(3) \times 2$ & $2.20(1)$ & $\mathrm{M}(2)-\mathrm{O}(3)$ & $2.03(1)$ \\
Mean & $\mathbf{2 . 2 3}$ & $\mathrm{M}(2)-\mathrm{O}(5)$ & $2.07(1)$ \\
& & $\mathrm{M}(2)-\mathrm{O}(1)$ & $2.133(9)$ \\
& & $\mathrm{M}(2)-\mathrm{O}(5)$ & $2.35(1)$ \\
$\mathrm{P}(1)-\mathrm{O}(2) \times 2$ & $1.54(1)$ & $\mathrm{Mean}$ & $\mathbf{2 . 0 8}$ \\
$\mathrm{P}(1)-\mathrm{O}(1) \times 2$ & $1.74(1)$ & $\mathrm{O}(2)-\mathrm{P}(1)-\mathrm{O}(2)$ & $99.2(9)$ \\
Mean & $\mathbf{1 . 6 4}$ & $\mathrm{O}(1)-\mathrm{P}(1)-\mathrm{O}(1) \times 2$ & $115.6(8)$ \\
& & $\mathrm{O}(2)-\mathrm{P}(1)-\mathrm{O}(1) \times 2$ & $105.0(8)$ \\
& & $\mathrm{Mean}$ & $110.9(8)$ \\
$\mathrm{P}(2)-\mathrm{O}(4)$ & $1.62(1)$ & $\mathrm{O}(3)-\mathrm{P}(2)-\mathrm{O}(5)$ & $\mathbf{1 0 9 . 5}$ \\
$\mathrm{P}(2)-\mathrm{O}(6)$ & $1.51(1)$ & $\mathrm{O}(6)-\mathrm{P}(2)-\mathrm{O}(3)$ & $114.4(8)$ \\
$\mathrm{P}(2)-\mathrm{O}(3)$ & $1.49(1)$ & $\mathrm{O}(4)-\mathrm{P}(2)-\mathrm{O}(5)$ & $111.4(8)$ \\
$\mathrm{P}(2)-\mathrm{O}(5)$ & $1.55(1)$ & $\mathrm{O}(6)-\mathrm{P}(2)-\mathrm{O}(5)$ & $103.9(8)$ \\
Mean & $\mathbf{1 . 5 4}$ & $\mathrm{O}(4)-\mathrm{P}(2)-\mathrm{O}(3)$ & $106(1)$ \\
& & $\mathrm{O}(6)-\mathrm{P}(2)-\mathrm{O}(4)$ & $108.4(8)$ \\
& & Mean & $113(1)$ \\
& & & $\mathbf{1 0 9 . 5}$ \\
\hline
\end{tabular}

By increasing reaction time, it appears that the $\mathrm{Fe}^{3+}$-content of alluaudites increases significantly, as well as their Na-content. Since the oxidation conditions were identical in all experiments, it appears that the Na-increase was due to the better ordering of cations on site $\mathrm{A}(1)$ of sample $48 \mathrm{~h}$, favored by a longer synthesis duration.

\subsection{Mössbauer spectroscopy}

Iron-57 Mössbauer spectroscopy was used to study the Fe valence state, local environment and the relative amounts of iron containing phases in the NMFP samples. The Mössbauer spectral parameters of the pure NMFP phases obtained at $220{ }^{\circ} \mathrm{C}$ after $6,12,24$ and $48 \mathrm{~h}$ recorded at room temperature are shown in Fig. 3 and their corresponding hyperfine parameters are given in Table 4. All spectra are consistent with the presence of paramagnetic iron, confirming the absence of any magnetic ordering at room temperature. Good quality fits of the data have been obtained by using only a model with three iron types modeled by three doublets. The isomer shift and quadrupole splitting values are in good agreement with the existence of one iron site with a small isomer shift and quadrupole splitting occupied by high-spin $\mathrm{Fe}^{3+}$, and two iron sites with a large isomer shift and quadrupole splitting assigned to high spin $\mathrm{Fe}^{2+}$. Indeed, at least three pronouncedly separated surroundings of iron ions can be distinguished in the structure of NMFP which is in good agreement with previously published data [28]. Our fitting approach considers a random distribution of $\mathrm{Fe}^{2+}, \mathrm{Fe}^{3+}$, and $\mathrm{Mn}^{2+}$ at the M2 site while the M1 site is filled with $\mathrm{Mn}^{2+}$ [8] which is in good agreement with the XRD. The Mössbauer spectra show one Fe(III) doublet, corresponding to $\mathrm{Fe}(\mathrm{III})$ on the $\mathrm{M}(2)$ site, as well as two Fe(II) doublets, one at M(1) and other at M(2) (Table S2). An alluaudite-type compound with the same chemical composition, $\mathrm{Na}_{2} \mathrm{MnFe}(\mathrm{II}) \mathrm{Fe}(\mathrm{III})(\mathrm{PO} 4) 3$, was synthesized hydrothermally at $400{ }^{\circ} \mathrm{C}$ by Hatert et al. [8], and the Mössbauer spectrum is significantly different. Indeed, Hatert et al. observed two $\mathrm{Fe}(\mathrm{III})$ doublets and two Fe(II) doublets, all of them assigned to iron on the $M(2)$ site. However, in our case, only one doublet is observed for $\mathrm{Fe}(\mathrm{III})$, and one $\mathrm{Fe}(\mathrm{II})$ doublet shows a smaller quadrupole splitting of ca. $2.17 \mathrm{~mm} / \mathrm{s}$, compared to the values obtained by Hatert et al. [8], of ca. $2.64 \mathrm{~mm} / \mathrm{s}$. This doublet is consequently assigned to Fe(II) on the $\mathrm{M}(1)$ site.

With increasing of heat treatment time, no change in spectral shape is observed. The values of both the isomer shift $(\delta)$ and the quadrupole splitting $(\Delta)$ do not change significantly. All compounds exhibit 


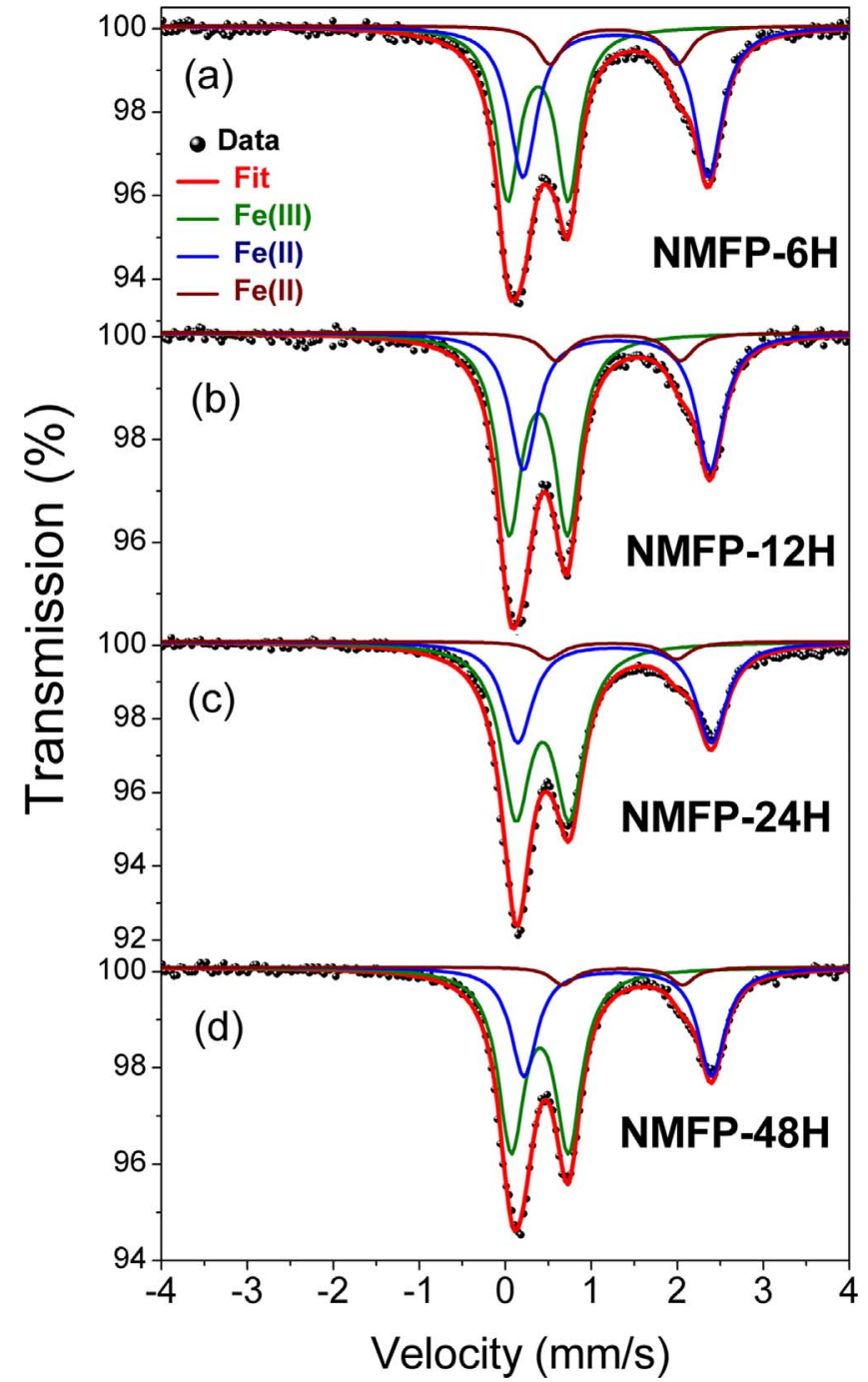

Fig. 3. Room temperature Mössbauer spectra of NMFP powder synthesized by hydrothermal method at $220^{\circ} \mathrm{C}$ after 6, 12, 24 and $48 \mathrm{~h}$, named (a) NMFP-6H, (b) NMFP-12H, (c) NMFP-24H and (d) NMFP-48H respectively.

Table 4

Fitted Mössbauer parameters ${ }^{\mathrm{a}}$ for NMFP phases obtained after 6, 12, 24 and $48 \mathrm{~h}$, by maintaining the temperature of the reaction at $220{ }^{\circ} \mathrm{C}$.

\begin{tabular}{llllll}
\hline & & NMFP-6 $\mathrm{h}$ & $\mathrm{NMFP}-12 \mathrm{~h}$ & $\mathrm{NMFP}-24 \mathrm{~h}$ & $\mathrm{~N}$ NFP-48 \\
\hline $\mathrm{Fe}^{3+}(1)$ & $\delta(\mathrm{mm} / \mathrm{s})$ & $0.37(4)$ & $0.37(4)$ & $0.38(2)$ & $0.37(1)$ \\
& $\Delta(\mathrm{mm} / \mathrm{s})$ & $0.70(1)$ & $0.67(1)$ & $0.65(1)$ & $0.66(1)$ \\
& $\Gamma(\mathrm{mm} / \mathrm{s})$ & $0.33(1)$ & $0.34(1)$ & $0.40(2)$ & $0.40(1)$ \\
& Area (\%) & $44(1)$ & $51(2)$ & $58(2)$ & $59(2)$ \\
$\mathrm{Fe}^{2+}(2)$ & $\delta(\mathrm{mm} / \mathrm{s})$ & $1.28(1)$ & $1.29(1)$ & $1.28(1)$ & $1.30(1)$ \\
& $\Delta(\mathrm{mm} / \mathrm{s})$ & $2.15(2)$ & $2.16(2)$ & $2.18(2)$ & $2.18(2)$ \\
& $\Gamma(\mathrm{mm} / \mathrm{s})$ & $0.38(1)$ & $0.38(1)$ & $0.40(1)$ & $0.37(1)$ \\
& Area (\%) & $46(1)$ & $41(1)$ & $36(2)$ & $36(2)$ \\
$\mathrm{Fe}^{2+}(3)$ & $\delta(\mathrm{mm} / \mathrm{s})$ & $1.26(2)$ & $1.28(2)$ & $1.24(2)$ & $1.30(2)$ \\
& $\Delta(\mathrm{mm} / \mathrm{s})$ & $1.48(5)$ & $1.44(2)$ & $1.49(2)$ & $1.43(1)$ \\
& $\Gamma(\mathrm{mm} / \mathrm{s})$ & $0.35(1)$ & $0.37(1)$ & $0.37(1)$ & $0.33(1)$ \\
& Area (\%) & $10(1)$ & $8(1)$ & $6(1)$ & $5(2)$
\end{tabular}

${ }^{a} \delta$-Isomer shift, referred to $\alpha$-iron at $295 \mathrm{~K}, \Delta$ - quadrupole splitting, $\Gamma$ - line width.

approximately the same isomer shifts and quadrupole splitting within the limits of experimental error confirming that reaction time does not significantly modify the atomic structure.
The Mössbauer results show that $\mathrm{Fe}^{3+}$ content progressively increases with the reaction time. Note that the relative spectral area is not exactly equivalent to the concentration because of possible small differences in the $\mathrm{Fe}(\mathrm{II})$ and $\mathrm{Fe}(\mathrm{III})$ Lamb-Mössbauer factor. The relative area of the three components changes in the Mössbauer spectra with increasing time reaction from 6 to $48 \mathrm{~h}$. The relative area of $\mathrm{Fe}(\mathrm{III})$ component peak increases from $44 \%$ to $59 \%$. This may be due to oxidation reaction of $\mathrm{Fe}(\mathrm{II})$ in presence of nitrates [29].

\subsection{NMFP particles morphology}

Pure NMFP compound (as shown by XRD results) with dandelion sphere-like particles was obtained after only $6 \mathrm{H}$ (Fig. 4a, b). However, the hydrothermal reaction was prolonged to $12,24-48 \mathrm{~h}$ to investigate the effect of reaction time on NMFP particle morphology. The results show that by increasing the hydrothermal reaction time, the dandelion sphere-like particles are progressively transformed in micro-rods (Fig. $4 c-h$ ). This particle morphology change takes place without modification of the crystalline phase, as proved by the XRD results presented in the previous section.

If we examine the sequence of micrographs in more detail, we observe that after $12 \mathrm{~h}$ (Fig. $4 \mathrm{c}$, d), some dandelion sphere-like particles formed after $6 \mathrm{~h}$ of reaction are destroyed in favor of formation of micro-rods. By increasing the hydrothermal treatment time to $24 \mathrm{~h}$ (Fig. 4e, f), the dandelion sphere-like particles are progressively transformed in micro-rod particles. Finally, by increasing the reaction time to $48 \mathrm{~h}$ (Fig. $4 \mathrm{~g}, \mathrm{~h}$ ), a self-assembled micro-rods particles morphology is observed. This result confirms that the hydrothermal reaction duration has a great influence on the morphological properties of NMFP powders.

\subsection{TGA and DSC characterization}

Fig. 5 displays typical thermogravimetric (TG) and Differential Scanning Calorimetry (DSC) of NMFP material in air atmosphere at a heating rate of $2.5^{\circ} \mathrm{C} / \mathrm{min}$. NMFP thermal analysis points out that the material did not experience any thermal decomposition up to $500^{\circ} \mathrm{C}$. Moreover, when the temperature reaches $500{ }^{\circ} \mathrm{C}$, the material transforms in $\square_{0.5} \mathrm{Na}_{1.5} \mathrm{Mn}_{1.5} \mathrm{Fe}_{1.5}\left(\mathrm{PO}_{4}\right)_{3}$ isostructural alluaudite [26], which is the most stable compound of this group until $1000{ }^{\circ} \mathrm{C}$ and beyond. This behavior justifies the high thermal stability of this NMFP cathode materials and it is in a good agreement with high thermal stability of iron phosphate compounds [30]. This parameter is an additional crucial behavior that qualifies NMFP as a suitable candidate for $\mathrm{Na}$ and Li cathode materials. The DSC trace reveals an endothermic peak after $800{ }^{\circ} \mathrm{C}$ without mass loss that could be attributed to a phase ordering transition.

\subsection{Electrochemical measurements}

The electrochemical properties of four NMFP (NMFP-6H, NMFP$12 \mathrm{H}$, NMFP-24H, NMFP-48H) samples were evaluated as positive electrode in hybrid cells in 1.5-4.5 V voltage range at room temperature. The electrochemical properties of all samples were evaluated without any further optimization such as particle size reduction or carbon coating.

Fig. 6a shows the comparison of the discharge capacity evolution of studied NMFP electrode materials at $\mathrm{C} / 5$ charge/discharge rates during 50 cycles. NMFP-electrodes show different first discharge capacities, the values were $48,40,34$ and $34 \mathrm{~mA} \mathrm{~h} \mathrm{~g}^{-1}$ for the samples obtained after 6 , 12, 24 and $48 \mathrm{~h}$, respectively. Then, all samples show excellent capacity retention of about $99 \%$ during 50 cycles. Enhanced electrochemical performance was obtained for the samples prepared during short and moderate hydrothermal reaction time (NMFP-6H and NMFP-12H). This difference is due to synthesis time which affects the particle size and morphology, the sintering and porosity of the particles. 

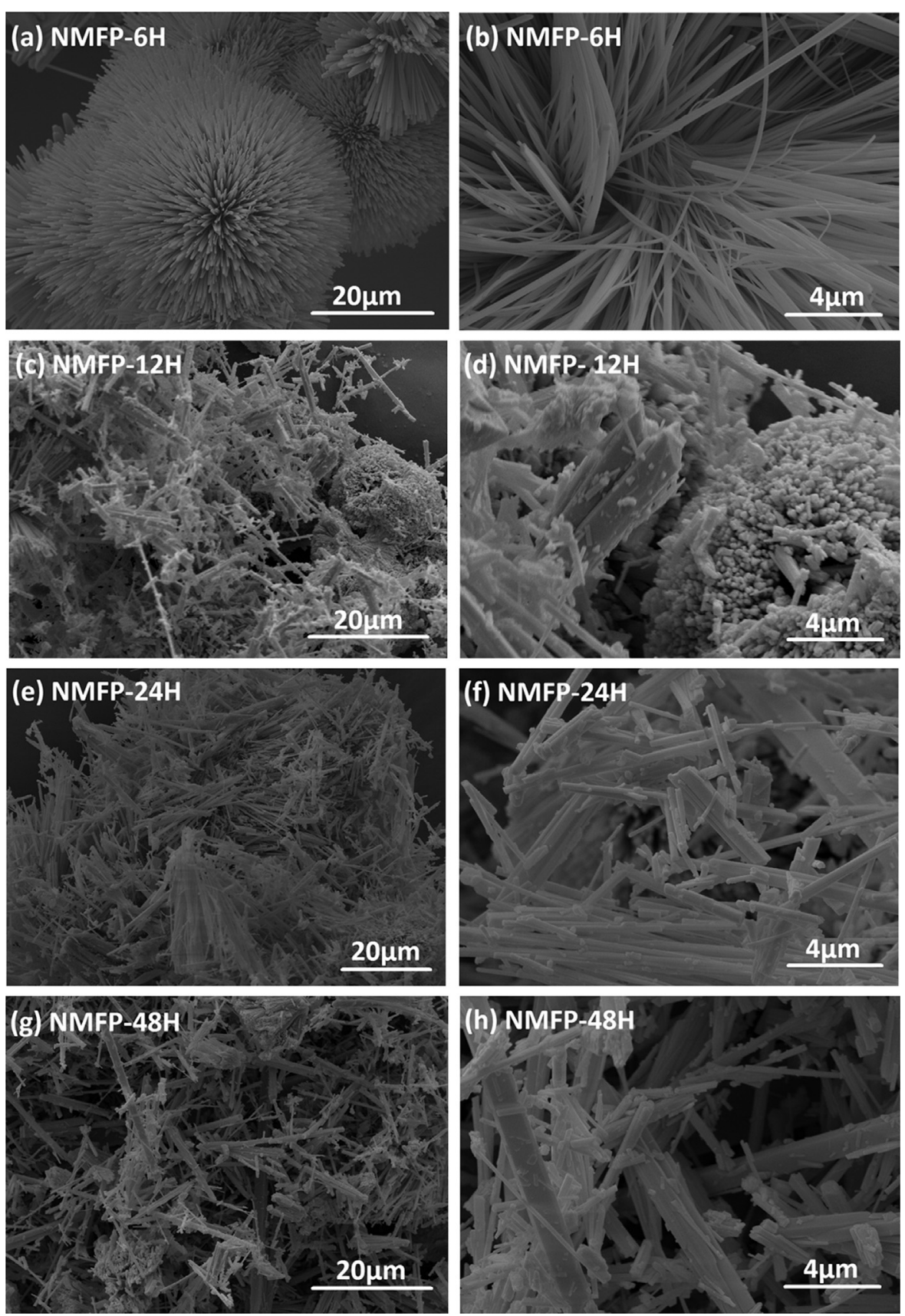

Fig. 4. SEM micrographs of (a, b) NMFP-6H, (c, b) NMFP-12H, (e, f) NMFP-24H and (g, h) NMFP-48H particles prepared by hydrothermal synthesis at $220{ }^{\circ} \mathrm{C}$.

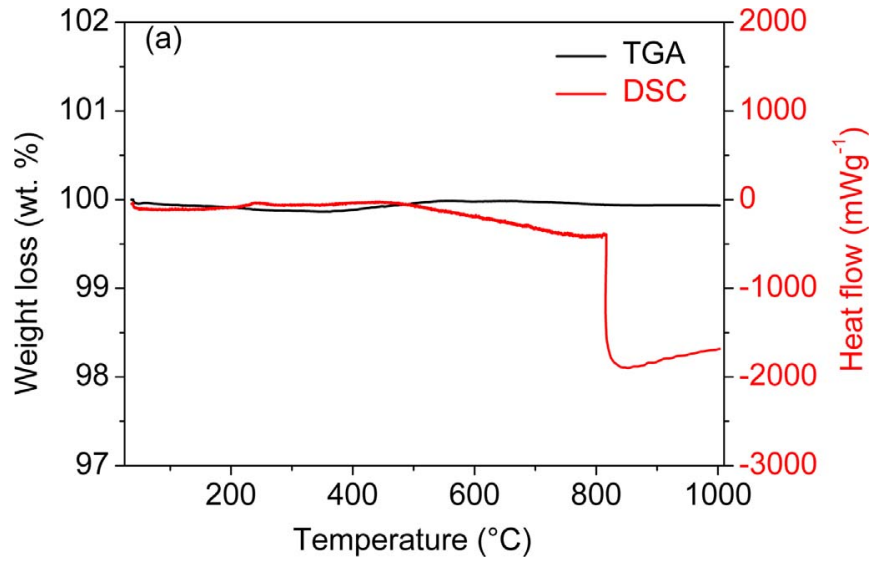

Fig. 5. TGA-DSC curves of NMFP compound, in air, $2.5^{\circ} \mathrm{C} / \mathrm{min}$.
Fig. 6b displays selected galvanostatic charge/discharge curves of NMFP-6H, NMFP-12H, NMFP-24H and NMFP-48H electrodes at $\mathrm{C} / 5$ charge/discharge rate in the $1.5-4.5 \mathrm{~V}$ voltage range. The comparison of the four samples shows that the capacity decreases with increasing hydrothermal reaction time. The growth of the particle size correlated to the reaction time (Fig. 4) may be the main parameter that leads to the capacity drop for the samples with long reaction time. The four NMFP-samples exhibit similar charge/ discharge curve profiles with two peaks in the anodic scan observed at about 2.5 and $3.2 \mathrm{~V}$ associated to the oxidation of some $\mathrm{Fe}^{2+}$ and/ or $\mathrm{Mn}^{2+}$ ions. In the reverse voltage scan, the cathodic peaks at 2.7 and $2.3 \mathrm{~V}$ correspond to the reduction of $\mathrm{Fe}^{3+}$ and/or $\mathrm{Mn}^{3+}$ ions (Fig. $\mathrm{S} 1)$. These active voltage values were also observed in $\mathrm{NaMnFe}_{2}(\mathrm{PO} 4)_{3}$ [31]. The excellent cycling performances of NMFP-sample could be attributed to the high structural stability of NMFP with alluaudite structure. 

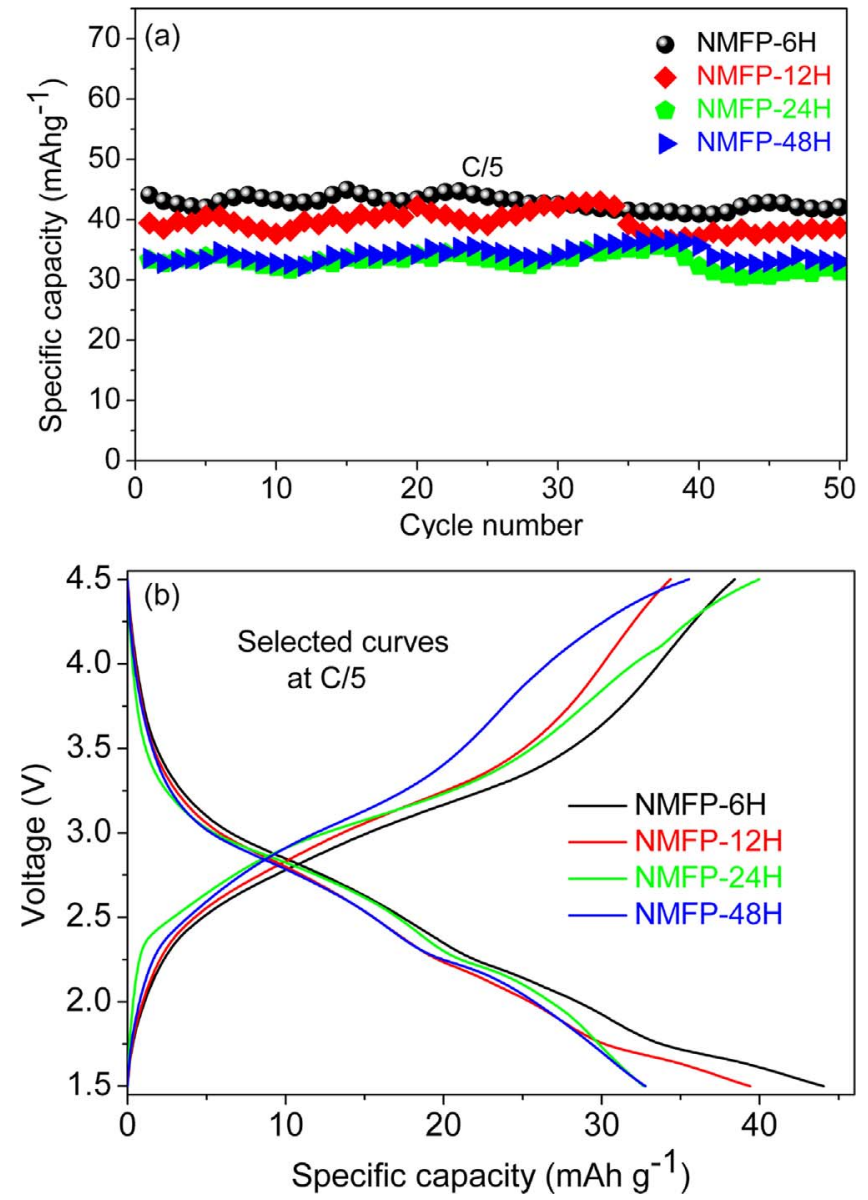

Fig. 6. (a) Evolution of discharge capacity vs. cycle number and (b) voltage profiles of selected cycle for NMFP electrode materials at $\mathrm{C} / 5$ charge/discharge rate in 1.5-4.5 V voltage range at room temperature.

The excellent capacity retention (Fig. 6a) shows that even though the NMFP theoretical capacity is low, NMFP might be a good electrode material for storing energy for stationary applications.

The rate performances of NMFP-electrode materials prepared at different hydrothermal reaction times are shown in Fig. 7, the electrode presents stable cycling behavior at various applied current densities of $\mathrm{C} / 15, \mathrm{C} / 10, \mathrm{C} / 5,1 \mathrm{C}$ and $4 \mathrm{C}$. At low current rate (C/15), the four NMFP-based cathode samples exhibit high first discharge capacities of about 64, 70, 67 and $64 \mathrm{~mA} \mathrm{~h} \mathrm{~g}^{-1}$ for NMFP-6H, NMFP-12H, NMFP-

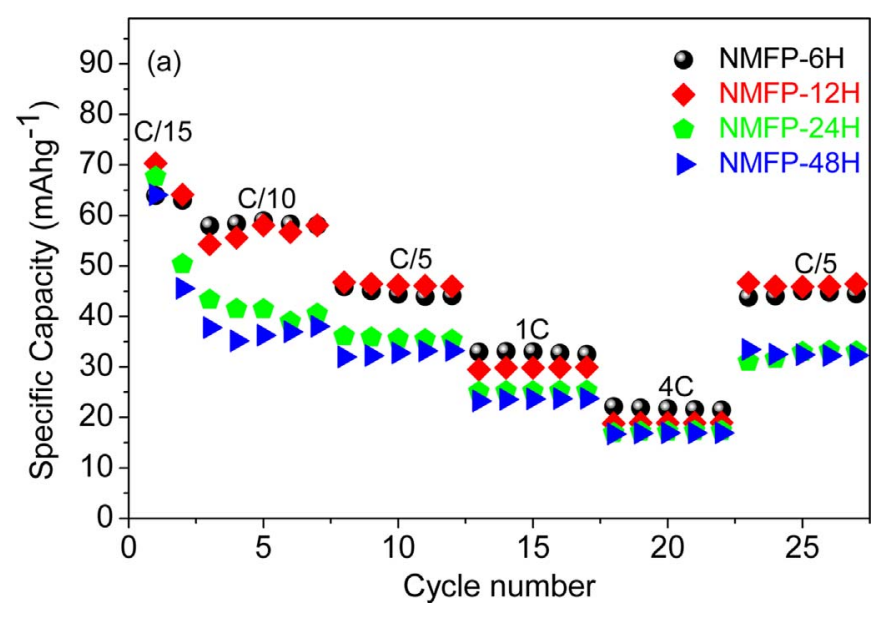

Fig. 7. Evolution of the discharge capacity of NMFP samples prepared at different hydrothermal reaction time on cycling at increasing rates from $\mathrm{C} / 15$ to $4 \mathrm{C}$.
24H and NMFP-48H, respectively. However, these capacities fade up significantly after first charge/discharge cycle especially for the samples prepared during long hydrothermal reaction time. This may be explained by the increase of particle size with increasing of the time of reaction (Fig. 4). In addition, the carbon black added during the electrode preparation only connects the secondary spherical particles, but cannot penetrate the inner pores between the primary particles [15].

The discharge capacities of all NMFP-samples decrease slightly with the increase of applied current densities, all samples show very stable cyclability at different charge/discharge rates. The rate capability displayed in Fig. 7 shows that NMFP-6H and NMFP-12H cathode materials deliver discharge capacities of about $64,59,45,34$ and $22 \mathrm{~mA} \mathrm{~h} \mathrm{~g}^{-1}$ and 70, 58, 46, 30 and $19 \mathrm{~mA} \mathrm{~h} \mathrm{~g}^{-1}$ at C/15,C/10, C/5, 1C and $4 \mathrm{C}$ current densities respectively. Except the first discharge capacity at $\mathrm{C} / 15$ current rate, the samples with long hydrothermal reaction time (NMFP-24H and NMFP-48H) deliver lower capacities at each tested current rate compared to NMFP-6H and NMFP-12H.

Fig. 8(a and b) show selected discharge curves for each tested current rate for the NMFP-6H and NMFP-48H samples. The typical voltage plateau at $2.8 \mathrm{~V}\left(\mathrm{vs} \mathrm{Li}^{+} / \mathrm{Li}\right)$ is observed for both electrodes at low current densities $(\mathrm{C} / 15, \mathrm{C} / 10$ and $\mathrm{C} / 5)$. As the discharge current density increases, the capacity decreases. A correlation between rate capability and cell polarization was observed for both NMFP samples (Fig. 8c). For NMFP-6H electrode material, the charge/discharge curve profiles at various current densities, $\mathrm{C} / 15, \mathrm{C} / 10, \mathrm{C} / 5,1 \mathrm{C}$ and $4 \mathrm{C}$ show slow increase in polarization with increasing of the cycling rate, but the curve shape illustrates a good $\mathrm{Na}^{+} / \mathrm{Li}^{+}$-extraction/insertion in the NMFP cathode material at different current densities. Thus, the NMFP-48H sample shows the highest cell polarization, compared to the NMFP-6H, (Fig. 8a) that leads to poor rate performances (Fig. 8b). This behavior is a consequence of the larger particle size (Fig. $4 \mathrm{~g}, \mathrm{~h}$ ) and material structure change due to the high $\mathrm{Fe}^{3+/} \mathrm{Fe}^{2+}$ ratio which limits intercalation/deintercalation of the lithium-ion in NMFP-structure. Large particles are less suited to ionic transport due to longer diffusion distances and higher charge transfer resistances. In their studies Mahmoud et al. and Kunduraci et al. separately confirm that the particle size affects the electrochemical performance of electrode materials, mainly at high current densities $[32,33]$.

Fig. 8c displays the Peukert plot for the NMFP samples prepared at different hydrothermal reaction time. The four NMFP-based cathode materials show a similar evolution of capacity when current density is increased. The NMFP-6H and NMFP-12H samples show the good capacity values for the tested current densities, confirming that the samples prepared during short hydrothermal reaction time exhibit the best rate capability compared to the samples prepared during long reaction time (NMFP-24H and NMFP-48H). As the particle size of the four NMFP samples grow with the hydrothermal reaction time, this may justify the good electrochemical performance of sample with short (NMFP-6H) and moderate (NMFP-12H) hydrothermal reaction time. These results show the importance of the electrode materials preparation with well controlled particle morphology and size at moderate hydrothermal reaction time in order to improve the electrochemical performances of NMFP-based electrodes.

\section{Conclusions}

NMFP particles to be used as electrode materials for hybrid-ion batteries with promising electrochemical performances were successfully synthesized by hydrothermal method. Structural properties, particle size, morphology and electrochemical properties of prepared sodium manganese iron phosphate powders were greatly affected by the synthesis conditions. In this work, we showed that increasing hydrothermal treatment time leads to an increase in crystallinity and crystal stabilility of NMFP, the influence of reaction time on the morphological and electrochemical properties of the NMFP compound 

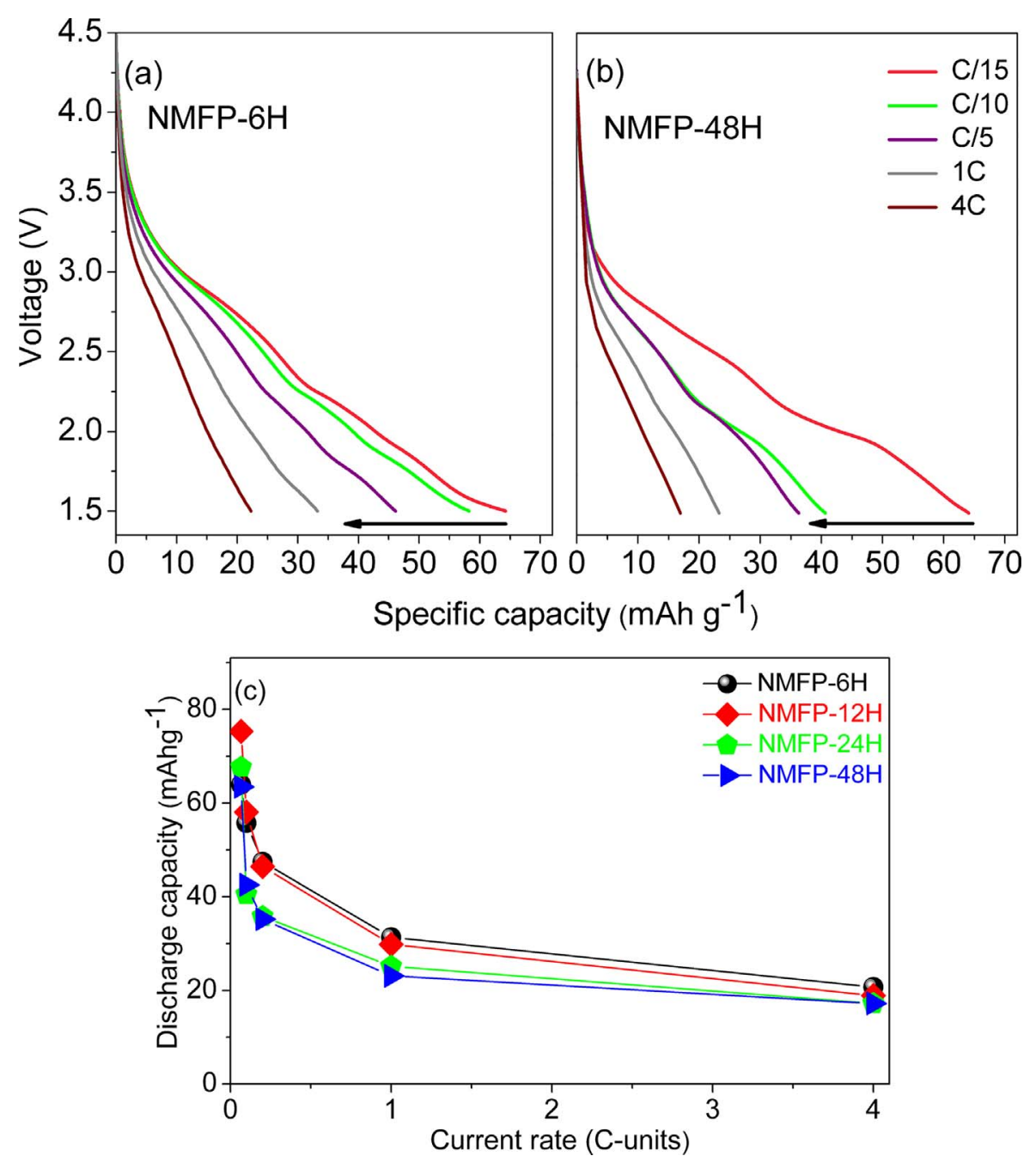

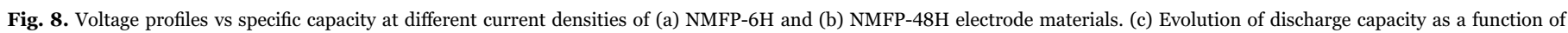
discharge rate for the four samples.

was also studied. The pure phase of the NMFP compound, selfassembled in dandelion sphere-like particles, was obtained by a one step hydrothermal synthesis route at $220^{\circ} \mathrm{C}$ after only $6 \mathrm{~h}$. Here, we show that the increase of reaction time from $6 \mathrm{~h}$ to 12,24 and $48 \mathrm{~h}$ has a strong effect on the particle morphology: the dandelion sphere-like morphology is degraded in favor of microrod formation, in good agreement with the Rietveld refinements of NMFP-6H, NMFP-12H, NMFP-24H and NMFP-48H, which show that the crystallite size of NMFP is inversely proportional to the reaction time.

NMFP materials were found to be interesting cathode candidates due to the availability and low cost of precursors used during synthesis. NMFP material is a low-cost material, and the synthesis protocol presented here, may be very interesting for industrial production. This protocol could be applied to study other materials of the same family as NMFP. The crystal structure characterization and electrochemical measurements have shown the simultaneous presence of the $\mathrm{Mn}^{2+/ 3+}$ and $\mathrm{Fe}^{2+/ 3+}$ redox couples in the pristine material and during electrochemical cycling. The comparison of the galvanostatic charge/discharge cycling measurements of the four samples with increasing of reaction time shows a small capacity decrease from NMFP-6H to NMFP-48H, that is due to the particle size and morphology growth and the concurrent decrease of the $\mathrm{Fe}^{2+} / \mathrm{Fe}^{3+}$ ratio as shown by Mössbauer spectroscopy. Therefore, even if the alluaudite material seems attractive from a structural point of view for alkaline metal intercalation/ deintercalation, the low electronic conductivity seems to be their major drawback. To enhance the electrochemical performance, conductivity improvement and size reduction to nanomaterial scale are surely required. In our roadmap for coming projects, the synthesis of alluaudite particles with optimized properties (conductivity, nanomaterials) is regarded as our main target.

\section{Acknowledgements}

The authors are grateful to the Walloon Region for support under the "PE Plan Marshall 2.vert" program (BATWAL - 1318146) and the University of Liege and FRS-FNRS for equipment grants and. C. Karegeya acknowledges the abroad study leave of the University of Rwanda. A. Mahmoud would like to thank the Walloon region for a Beware Fellowship Academia 2015-1, RESIBAT no. 1510399. This research was sponsored, in part, by UT-Battelle, LLC under Contract No. DE-AC05-00OR22725 with the U.S. Department of Energy (Mossbauer data analysis and manuscript edition by RPH).

\section{Appendix A. Supplementary material}

Supplementary data associated with this article can be found in the online version at doi:10.1016/j.jssc.2017.06.021.

\section{References}

[1] D.J. Fisher, Alluaudite, Am. Mineral. 40 (1955) 1100-1109.

[2] P.B. Moore, crystal-chemistry of alluaudite of structure type-contribution to 
paragenesis of pegmatite phosphate giant crystals, Am. Mineral. 56 (1971) 1955.

[3] F. Fontan, P. Huvelin, M. Orliac, F. Permingeat, La ferrisicklérite des pegmatites de Sidi Bou Othmane (Jebilet, Maroc) et le groupe des minéraux à structure de triphylite, Bull. Soc. Fr. Minéral. Cristal. 99 (1976) 274-286.

[4] F. Leroux, A. Mar, C. Payen, D. Guyomard, A. Verbaere, Y. Piffard, Synthesis and structure of $\mathrm{NaMn}_{3}\left(\mathrm{PO}_{4}\right)\left(\mathrm{HPO}_{4}\right)_{2}$, an unoxidized variant of the alluaudite structure type, J. Solid State Chem. 115 (1995) 240-246.

[5] M.B. Korzenski, G.L. Schimek, J.W. Kolis, G.J. Long, Hydrothermal synthesis, structure, and characterization of a mixed-valent iron (II/III) phosphate, $\mathrm{NaFe}_{3.67}\left(\mathrm{PO}_{4}\right)_{3}$ : a new variation of the alluaudite structure type, J. Solid State Chem. 139 (1998) 152-160.

[6] F. Hatert, P. Keller, F. Lissner, D. Antenucci, A.-M. Fransolet, First experimenta evidence of alluaudite-like phosphates with high Li-content, Eur. J. Mineral. 12 (2000) 847-857.

[7] F. Hatert, D. Antenucci, A.-M. Fransolet, M. Liégeois-Duyckaerts, The crystal chemistry of lithium in the alluaudite structure: a study of the $\left(\mathrm{Na}_{1-}{ }_{\mathrm{x}} \mathrm{Li}_{\mathrm{x}}\right)$ $\mathrm{CdIn}_{2}\left(\mathrm{PO}_{4}\right)_{3}$ solid solution $(\mathrm{x}=0-1)$, J. Solid State Chem. 163 (2002) 194-201.

[8] F. Hatert, L. Rebbouh, R.P. Hermann, A.-M. Fransolet, G.J. Long, F. Grandjean, Crystal chemistry of the hydrothermally synthesized $\mathrm{Na}_{2}\left(\mathrm{Mn}_{1-\mathrm{x}} \mathrm{Fe}_{\mathrm{x}}{ }^{2+}\right)_{2} \mathrm{Fe}^{3+}\left(\mathrm{PO}_{4}\right)_{3}$ alluaudite-type solid solution, Am. Mineral. 90 (2005) 653-662.

[9] G. Oyama, H. Kiuchi, S.C. Chung, Y. Harada, A. Yamada, Combined experimental and computational analyses on the electronic structure of alluaudite-type sodium iron sulfate, J. Phys. Chem. C 120 (2016) 23323-23328.

[10] F. Hatert, G.J. Long, D. Hautot, A.-M. Fransolet, J. Delwiche, M.-J. HubinFranskin, F. Grandjean, A structural, magnetic, and Mössbauer spectral study of several Na-Mn-Fe-bearing alluaudites, Phys. Chem. Miner. 31 (2004) 487-506.

[11] F. Hatert, Crystal chemistry of the divalent cation in alluaudite-type phosphates: a structural and infrared spectral study of the $\mathrm{Na}_{1.5} \square_{1.5} \mathrm{Fe}_{1.5}\left(\mathrm{PO}_{4}\right)_{3}$ solid solutions (x $=0-1, \mathrm{M}^{2+}=\mathrm{Cd}^{2+}, \mathrm{Zn}^{2+}$ ), J. Solid State Chem. 181 (2008) 1258-1272.

[12] M. Kacimi, M. Ziyad, F. Hatert, Structural features of $\mathrm{AgCaCdMg}_{2}\left(\mathrm{PO}_{4}\right)_{3}$ and $\mathrm{AgCd}_{2} \mathrm{Mg}_{2}\left(\mathrm{PO}_{4}\right)_{3}$, two new compounds with the alluaudite-type structure, and their catalytic activity in butan-2-ol conversion, Mater. Res. Bull. 40 (2005) 682-693.

[13] C. Durio, A. Daidouh, N. Chouaibi, C. Pico, M.L. Veiga, Electrical behavior of new orthophosphates $\mathrm{Na}_{2} \mathrm{M}_{3}(\mathrm{PO})_{3}\left(\mathrm{M}_{3}=\mathrm{GaMn}_{2}, \mathrm{GaCd}_{2}, \mathrm{InMn}_{2}\right.$ and FeMnCd) with alluaudite-like structure, J. Solid State Chem. 168 (2002) 208-216.

[14] T.J. Richardson, Phosphate-stabilized lithium intercalation compounds, J. Power Sources 119 (2003) 262-265.

[15] R. Essehli, H.B. Yahia, K. Maher, M.T. Sougrati, A. Abouimrane, J.-B. Park, Y.K. Sun, M.A. Al-Maadeed, I. Belharouak, Unveiling the sodium intercalation properties in $\mathrm{Na}_{1.86} \square_{0.14} \mathrm{Fe}_{3}\left(\mathrm{PO}_{4}\right)_{3}$, J. Power Sources 324 (2016) 657-664.

[16] K. Trad, D. Carlier, L. Croguennec, A. Wattiaux, M. Ben Amara, C. Delmas, Structural study of the $\mathrm{Li}_{0.5} \mathrm{Na}_{0.5} \mathrm{MnFe}_{2}\left(\mathrm{PO}_{4}\right)_{3}$ and $\mathrm{Li}_{0.75} \mathrm{Na}_{0.25} \mathrm{MnFe}_{2}\left(\mathrm{PO}_{4}\right)_{3}$ alluaudite phases and their electrochemical properties As positive electrodes in lithium batteries, Inorg. Chem. 49 (2010) 10378-10389.

[17] W. Huang, B. Li, M.F. Saleem, X. Wu, J. Li, J. Lin, D. Xia, W. Chu, Z. Wu, Selfassembled alluaudite $\mathrm{Na}_{2} \mathrm{Fe}_{3-\mathrm{x}} \mathrm{Mn}_{\mathrm{x}}\left(\mathrm{PO}_{4}\right)_{3}$ micro/nanocompounds for sodium-ion battery electrodes: a new insight into their electronic and geometric structure,
Chem. - Eur. J. 21 (2015) 851-860.

[18] K. Trad, D. Carlier, A. Wattiaux, M.B. Amara, C. Delmas, Study of a layered iron (III) phosphate phase $\mathrm{Na}_{3} \mathrm{Fe}_{3}\left(\mathrm{PO}_{4}\right)_{4}$ used as positive electrode in lithium batteries, J. Electrochem. Soc. 157 (2010) A947-A952.

[19] N. Yabuuchi, K. Kubota, M. Dahbi, S. Komaba, Research development on sodiumion batteries, Chem. Rev. 114 (2014) 11636-11682.

[20] K.T. Lee, T.N. Ramesh, F. Nan, G. Botton, L.F. Nazar, Topochemical synthesis of sodium metal phosphate olivines for sodium-ion batteries, Chem. Mater. 23 (2011) 3593-3600.

[21] H. Pan, Y.-S. Hu, L. Chen, Room-temperature stationary sodium-ion batteries for large-scale electric energy storage, Energy Environ. Sci. 6 (2013) 2338-2360.

[22] T. Drezen, N.-H. Kwon, P. Bowen, I. Teerlinck, M. Isono, I. Exnar, Effect of particle size on $\mathrm{LiMnPO}_{4}$ cathodes, J. Power Sources 174 (2007) 949-953.

[23] M.K. Devaraju, I. Honma, Hydrothermal and solvothermal process towards development of $\mathrm{LiMPO}_{4}(\mathrm{M}=\mathrm{Fe}, \mathrm{Mn})$ nanomaterials for lithium-ion batteries, Adv. Energy Mater. 2 (2012) 284-297.

[24] R.A. Young, A.C. Larson, C.O. Paiva-Santos, Rietveld Snalysis of X-ray and Neutron Powder Diffraction Patterns, Atlanta GA Sch. Phys. Ga. Inst. Technol., 1998.

[25] R.P. Hermann, V. Keppens, P. Bonville, G.S. Nolas, F. Grandjean, G.J. Long, H.M. Christen, B.C. Chakoumakos, B.C. Sales, D. Mandrus, Direct experimental evidence for atomic tunneling of europium in crystalline $\mathrm{Eu}_{8} \mathrm{Ga}_{16} \mathrm{Ge}_{30}$, Phys. Rev. Lett. 97 (2006) 017401.

[26] F. Hatert, The crystal chemistry of lithium in the alluaudite structure: a study of the $\left(\mathrm{Na}_{1-\mathrm{x}} \mathrm{Li}_{\mathrm{x}}\right)_{1.5} \mathrm{Mn}_{1.5} \mathrm{Fe}_{1.5}\left(\mathrm{PO}_{4}\right)_{3}$ solid solution $(\mathrm{x}=0-1)$, Mineral. Petrol. 81 (2004) 205-217.

[27] F. Hatert, Etude cristallochimique et synthèse hydrothermale des alluaudites: contribution nouvelle au problème génétique des phosphates de fer et de manganèse dans les pegmatites granitiques et, partant, à celui de l'évolution de ces gisements. 〈http://orbi.ulg.ac.be/handle/2268/102892〉. (Accessed 16 June 2017).

[28] F. Hatert, R.P. Hermann, A.-M. Fransolet, G.J. Long, F. Grandjean, A structural, infrared, and Mössbauer spectral study of rosemaryite, $\mathrm{NaMnFe}^{3+} \mathrm{Al}\left(\mathrm{PO}_{4}\right)_{3}$, Eur. J. Mineral. 18 (2006) 775-785.

[29] J.C. Fanning, The chemical reduction of nitrate in aqueous solution, Coord. Chem. Rev. 199 (2000) 159-179.

[30] P. Moreau, D. Guyomard, J. Gaubicher, F. Boucher, Structure and stability of sodium intercalated phases in olivine $\mathrm{FePO}_{4}$, Chem. Mater. 22 (2010) 4126-4128.

[31] K. Trad, D. Carlier, L. Croguennec, A. Wattiaux, M. Ben Amara, C. Delmas, $\mathrm{NaMnFe}_{2}\left(\mathrm{PO}_{4}\right)_{3}$ alluaudite phase: synthesis, structure, and electrochemical properties as positive electrode in lithium and sodium batteries, Chem. Mater. 22 (2010) 5554-5562.

[32] A. Mahmoud, J.M. Amarilla, I. Saadoune, Effect of thermal treatment used in the sol-gel synthesis of $\mathrm{Li}_{4} \mathrm{Ti}_{5} \mathrm{O}_{12}$ spinel on its electrochemical properties as anode for lithium ion batteries, Electrochim. Acta 163 (2015) 213-222.

[33] M. Kunduraci, G.G. Amatucci, The effect of particle size and morphology on the rate capability of $4.7 \mathrm{~V} \mathrm{LiMn}{ }_{1.5+\delta} \mathrm{Ni}_{0.5-\delta} \mathrm{O}_{4}$ spinel lithium-ion battery cathodes, Electrochim. Acta 53 (2008) 4193-4199. 